\title{
TEXT-IMMANENT
}

MEANING:

INTEGRATIONIST

AND TERMINOLOGICAL

APPROACHES TO THE

INDETERMINACY

OF THE SIGN

\section{SIGNIFICADO TEXTO-IMANENTE: ABORDAGENS INTEGRACIONISTAS E TERMINOLÓGICAS PARA A INDETERMINAÇÃO DO SIGNO}

\author{
SIGNIFICADO TEXTO-INMANENTE: ENFOQUES INTEGRACIONISTAS Y TERMINOLÓGICOS \\ A LA INDETERMINACIÓN DEL SIGNO
}

Bassey. E. Antia*

University of the Western Cape | South Africa

\begin{abstract}
In this article, I put the fields of terminology and integrationism in conversation over the question of the indeterminacy of the sign. I employ the lenses offered by both paradigms to discuss data on the indeterminacy of terms in a text on legislative procedure. I argue that the data appear to confirm several related integrationist notions, including meaning-making as idiosyncratic contextualization and the reflexivity principle, thus making it apparent how the field of terminology can leverage on the integrationist philosophy of language to enhance its explanatory power. However, I also argue that theoretical insights from text-based terminology can serve as a corrective to perceptions of radical indeterminacy of the sign in integrationism. KEY WORDS: Terminology. Integrationism. Indeterminacy.
\end{abstract}

RESUMO: Neste artigo, coloco os campos da terminologia e do integracionismo em discussão sobre a questão da indeterminação do signo. Emprego as lentes oferecidas por ambos os paradigmas para discutir dados sobre a indeterminação dos termos em um texto sobre processo legislativo. Eu defendo que os dados parecem confirmar várias noções integracionistas interrelacionadas, incluindo a construção do significado como contextualização idiossincrática e o princípio da reflexividade. Isso evidencia como o campo da terminologia pode alavancar a filosofia integracionista da linguagem para potencializar seu poder explicativo. No 
entanto, também argumento que os insights teóricos da terminologia baseada em texto podem servir como um corretivo para as percepções de indeterminação radical do signo no integracionismo.

PALAVRAS-CHAVE: Terminologia. Integracionismo. Indeterminação.

RESUMEN: En este artículo pongo en conversación los campos de la terminología y el integracionismo sobre la cuestión de la indeterminación del signo. Utilizo las lentes que ofrecen ambos paradigmas para discutir datos sobre la indeterminación de términos en un texto sobre procedimiento legislativo. Sostengo que los datos parecen confirmar varias nociones integracionistas relacionadas, incluida la creación de significado como contextualización idiosincrásica y el principio de reflexividad, lo que hace evidente cómo el campo de la terminología puede aprovechar la filosofía integracionista del lenguaje para mejorar su poder explicativo. Sin embargo, también sostengo que las percepciones teóricas de la terminología basada en texto pueden servir como correctivo a las percepciones de indeterminación radical del signo en el integracionismo.

PALABRAS CLAVE: Terminología. Integracionismo. Indeterminación.

\section{INTRODUCTION}

In language and communication, the notion of indeterminacy jolts us out from an uncritical mentalism about, for instance, word meanings. It does so by problematizing the knowability of what meaning attaches or will attach to the use of a word in advance of such use, and without some further observational cues (QUINE, 1960). Quine argues that the fact of language being a social art, on the one hand, compels its users "to depend entirely on intersubjectively available cues as to what to say and when" (or what to mean) and, on the other, removes any "justification for collating linguistic meanings, unless in terms of [users'] dispositions to respond overtly to socially observable stimulations" (QUINE, 1960, p. ix). Rejecting this behavioralism, an even more radical approach to meaning problematizes the very idea of the pre-existence of meaning understood as "[...] a conceptual content to be identified - correctly or incorrectly - in verbal communication" (HARRIS, 1996, p. 233).

It is this same question of the indeterminacy of context-independent reference, and of the conditions under which some determinacy is achieved, that underlies Wittgenstein's philosophical reflections on language-games (WITTGENSTEIN, 1953). For language philosophers Quine and Wittgenstein, then, whether it is a linguist trying to make sense of gavagai uttered (in a language of interest) by a local on spotting a rabbit, or of water that is uttered among interlocutors who share a common language, momentary determinacy is purchased ultimately through observational behaviour. These are not simply pastimes of buffs of philosophy. These questions involve discussions of meaning-making, and have practical import for text readers, students, translators, lexicographers, among others.

The above tradition of reflecting on the in/determinacy of the sign is one that has been continued, sometimes in fundamentally different ways, in two relatively less well-known bodies of linguistics scholarship, namely, integrationism (HARRIS, 1996; 2015; DUNKER, 2019; BADE; PABLÉ, 2012) and terminology (SAGER, 1990; WRIGHT; BUDIN, 1997; CABRÉ, 1999; PICHT; DRASKAU, 1986; ANTIA, 2000; 2007). Regrettably, both bodies of scholarship have had precious little contact with each other, with the consequence that they have not been able to leverage on their respective insights for a number of purposes, e.g., to enhance their explanatory power, gain traction beyond a narrow circle of buffs, and perhaps self-correct. Thus, in its engagements with indeterminacy, terminology has not been able to draw on integrationism's demythification of language and the associated metadiscursive regime. On the other hand, the view that integrationism has traditionally had a relatively thin database (MAKONI, 2014) means that this approach could well do with subjecting its tenets to wider scrutiny in more naturally occurring contexts.

In this article, I put the fields of terminology and integrationism in conversation with each other over the question of the indeterminacy of the sign. I employ the lenses offered by both paradigms to discuss data on the indeterminacy of terms in a text on legislative procedure. I argue that the data appear to confirm several related integrationist notions, including meaning-making as idiosyncratic contextualization and the reflexivity principle, thus making it apparent how the field of terminology can leverage on the integrationist philosophy of language to enhance its explanatory power. 
However, I also argue that theoretical insights from text-based terminology can serve as a corrective to perceptions of radical indeterminacy of the sign in integrationism. Specifically, I suggest that some models of the term/sign in text-based terminology allow for a version of indeterminacy of the sign that is quite compatible with some notion of the sign being established by practices in a community; in other words, the sign's culturally underpinned or macrosocial stability. This conclusion is shown to be supported by the scholarship on complex systems.

There is an important caveat. In pursuing the above ends, this article is no doubt one of an increasing number of contributions by individuals who have had different career trajectories and interests dialoguing with integrationism. Ordinarily, this is an enterprise that is fraught with a range of conceivable risks; thankfully, however, integrationists are by the very precepts of their scholarship committed to the idea that sense-making (including of the integrationist paradigm) occurs within the context of variant experiences. This openness is exemplified by integrationist scholar, Peter Jones, with whom I have had discussions and for whose generosity I am grateful. Indeed, this is what makes dialoguing with integrationism less foreboding. Thus, in a recent volume (MAKONI; VERITY; KAIPER-MARQUEZ, 2021), non-integrationists are able to dialogue with integrationism from the standpoints of, for instance, rhetoric (CHIRINDO, 2021), multisemioticity (ANTIA; MAFOFO, 2021) and a theory of languaging without language (SABINO, 2021). They point out unique insights which integrationism is seen to offer the research areas from which they write (and at the moment of writing); but in integrating integrationism into concerns in these research areas, they also point out its weaknesses.

\section{INTEGRATIONISM AND TEXT-BASED TERMINOLOGY}

Integrationism lays bare a number of what are considered as myths and fallacies around Western European conceptions of language, in a bid to move away from an understanding of language as some specimen or extract that is placed in a cold and detached laboratory space for observation. Integrationism seeks to re-place language in the real world, and thus reclaim the layinflected experience of language as the basis of scholarship. It deprecates a code or pre-engineered view of language, seeing such a conceptualization as being at the heart of putative fallacies relating to the determinacy of the sign. One such fallacy is 'segregationism', the assumption that linguistic signs can have meaning independently of the real-world activities of signusers/makers, and of other semiotic systems. Another involves 'telementation', a fallacy grounded in mechanized transmission that sees communication as transfer of pre-determinate signs in a pre-established code from one head to another. An important assumption of these fallacies is a putative myth of social convention underlying language use. Harris, pioneer and foremost theorist of integrationism, argues that to understand sign and signification, it is erroneous " [...] to start with the notion of a social convention already in situ. For our own experience tells us that we attribute significations to things and events, irrespective of whether there is any social convention about the matter or not. Signs do not necessarily have a social dimension at all" (HARRIS, 1996, p. 67-8).

Integrationism substitutes for these fallacies a number of ideas that both highlight the radical indeterminacy of signs and the conditions under which one can speak of (momentary) determinacies. It sees signs as the products, rather than requisites, of communication. The integrationist argument is that a sign is "[...] the product of creative and purposive activity [and it] does not preexist that activity as something one finds, takes and interprets" (BADE; PABLÉ 2012, p. 57). This echoes the view by Harris that what "[...]constitutes a sign is not given independently of the situation in which it occurs or of its material manifestation in that situation" (HARRIS, 1996, p. 154). Communication is seen as ineluctably unfolding in the context of episodes in the real lives of the individuals communicating. It is into these episodes (comprising, among others, biographical dimensions, spaces, activities, and temporalities) that signs are simultaneously integrated and from which they derive their idiosyncratic meanings. Beyond the particular instances or episodes, what are left of the used or constituted signs are traces, but these traces do not obviate the need for subsequent active processes of sign-making and sign interpreting. We may have memories (sensu traces) of particular kisses, smells or headaches, but these particular events are singular, as Duncker argues. In brief, the "[...] integrational sign is a unique event, and it has no mode of existence outside the communicational episode in which it happened" (DUNCKER, 2019, p. 121). 
Just how, then, are humans able to communicate? The integrationist's communication infrastructure resides in "[...] what the human being is physiologically equipped to do, what the human being is collectively conditioned to do, and what the human being is individually aiming to do in given circumstances" (HARRIS, 1984, p. 280 apud DUNKER, 2019, p. 22). Respectively, biomechanical, macrosocial, and circumstantial factors constitute the pillars of the integrationist's sign-making or communicational proficiency. To cite Dunker (2019: 108), the "individual participant must be able to integrate, to "fit together" the exercise of various biomechanical capacities with acquaintance with "[...] culture-specific patterns of organisation within which the current communication situation occurs", in a way that makes sense to this person (HARRIS, 1993, p. 322)”. The singularity of every sign derives from the unique factors or perspectives integrated by the sign maker to birth it. While the addressee is biochemically incapable of adopting the original sign maker's perspective in "any absolute sense", they are nonetheless able to imagine it (DUNKER, 2017, p. 149). For a sign that is by definition private to become public, a minimum requirement is that "[individual] A assign a semiological value to $\mathrm{x}$, and [individual] $\mathrm{B}$ assign a semiological value to $\mathrm{x}$, and that $\mathrm{A}$ and $\mathrm{B}$ both carry out mutually integrated programmes of activity on that basis" (HARRIS, 2000, p. 70 quoted by DUNKER, 2017, p. 116). The constant action required in sign-making, the idiosyncrasy in perpetuity, means that reflexivity is a feature of communication. This idiosyncrasy is also a statement to the effect that scholarly interest in language should proceed from, or at least privilege, the (firstperson) perspective of the language/sign user.

Let us turn now to terminology, which is far from just being about dictionary-making. Scholarship in terminology focuses on "[...] specialised or specific subject areas within which it studies knowledge (units, structure, representation, evolution, acquisition, etc.) in its relation to expression (ANTIA, 2000, p. xv). Specialized knowledge contexts, unlike so-called general language use/texts, are contexts in which language has traditionally been used in a manner that is assumed to be more controlled on account of the specificities of the knowledge content, the participants in these discourses and the settings in which such discourses take place (CABRÉ, 1999). In studies of the behavior of terms in text (that is, text-based terminology), indeterminacy is widely considered as instability of the concept-term link which then raises different degrees of difficulty of correlation (GERZYMISCH-ARBOGAST, 1996; BOWKER, 1997; ROGERS, 2003; 2007; ANTIA, 2000; 2002; 2007; ANTIA; KAMAI, 2016). Consider the following sets, with the items in each set being used interchangeably for a common reference: central nervous system vs. brain and spinal cord; azotobacter vs. nitrogen fixing bacteria; life boat vs. pneumatic boat. If we assume experts of the respective subject areas may have no difficulty establishing equivalences of this kind, this is not a given for all text readers.

Analysis of terms in specialized text corpora (genetics, optical scanning technology, glaciology, muffling system in breathing aids, monetary economics, textbook biology, etc.) has led text-based terminology to rebut the claim that terms "bring their contexts with them" (NEWMARK, 1996, p. 194), or that terms are "precise and context-independent" (FLUCK, 1991, p. 47), or that terms need to be seen as determinate in contrast to ordinary words because of the contexts in which they occur. An example of this generic exceptionalism, disputed by text-based scholars of terminology, is seen in the following view by William Labov (1973, p.341):

Words have been called slippery customers, and many scholars have been distressed by their tendency to shift their meanings and slide out from under any simple definition. A goal of some clear thinkers has been to use words in more precise ways. But though this is an excellent and necessary step for technical jargon, it is a selfdefeating program when applied to ordinary words.

Text-based terminology locates several of the processes that produce indeterminacy in a number of interrelated sources, including the following:

1. Ontological multidimensionality, perspectivization or the notion of ways of seeing (BOWKER, 1997; GERZYMISCHARBOGAST, 1996; ANTIA, 2000; ANTIA; KAMAI, 2016). On account of the possible multiplicity of its dimensions, constituents, functions, users, and so on (recall the anecdote of the different tactile impressions of the proverbial elephant), a piece of intersubjectively verifiable reality can be designated, classified, or defined differently within and across texts, depending on what perspective is activated: color flatbed scanner vs. flatbed color scanner. There is thus a sense in which the viewpoint creates the (disciplinary) object. 
2. Textual considerations (HALLIDAY; MARTIN, 1993; LEMKE, 1990; ROGERS, 1999, ROGERS, 2007; 2008; CONDAMINES, 2010; PECMAN, 2014; ANTIA, 2002): On this view, explanations for variation in terms need to be sought in textual genre differences (including different text sections, e.g., title, introduction, body, etc.); in the constraints of thematic progression which may require nominalization and abridgement strategies, or contrarily, in the explication of previously densely encoded terms (e.g., release of hydrothermal event plumes --> mega plumes); in the constitution of the lexical chains through which text cohesion is achieved; in the deliberate action of the author to direct reader attention, or to sustain reader attention, curiosity and involvement; in the un/intended and co-text motivated shift in author focus, leading to what has been called author-specific contamination. See discussion below on Gerzymisch-Arbogast (1996).

3. Epistemological histories (AHMAD, 1996; CONDAMINES, 2010). On this view, explanations for variant terms and meanings may be obtained from a life-cycle perspective on concepts (form and meaning proliferate when concepts emerge, but are streamlined on consolidation); the nature of disciplines, especially the extent to which 'poetic license' in meaning-making is allowed; different schools of thought within disciplines or across disciplines in interdisciplinary areas (such as the 'environmental sciences')

To flesh out the point on ontological multidimensionality/perspectivization, which is somewhat relevant to the other dimensions listed above and is foundational for the ensuing analysis in this article, a brief overview of an aspect of Gerzymisch-Arbogast's (1996) term model is offered. The overview draws on the account in Antia \& Kamai (2016). The model's structuralist 'feel' and its infelicitous choice of terms (e.g., contamination) easily belie the key message, and as such reader perseverance is required.

In her approach to indeterminacy, Gerzymisch-Arbogast is keen to describe how, in special purpose communication, system-level specifications or abstractions of meaning, such as may be contained in normative resources (dictionaries, key texts) and/or may shape our expectations, can in fact be different from parole-level instantiations. Figure 1 is an adapted and simplified form of Gerzymisch-Arbogast's original model.
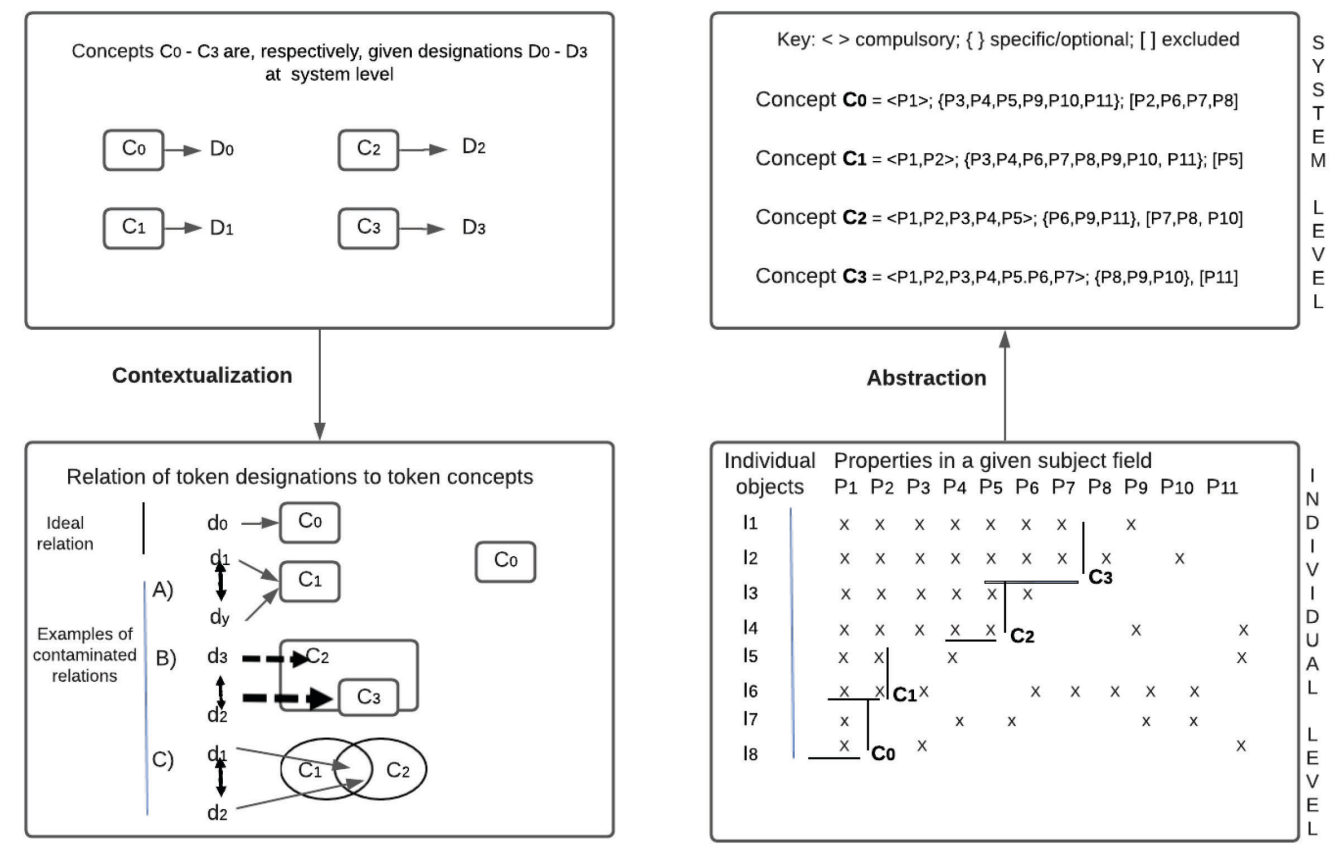

Figure 1: Adaptation of Gerzymisch-Arbogast's 1996 system-text terminology model

Source: Antia and Kamai (2016)

Starting from the bottom right pane of Figure 1, which is an individual, non-system level: in the ontological space or furniture of the universe that is of interest to specialists (e.g., economists, power engineers, geologists), there is a set of individual material or immaterial objects $l_{1}-1_{8}$. Different specialists, in other words, different groups of individuals, may associate features or properties with each of the objects. Interestingly, being specialists within each of the disciplines only means that the concerned individuals 
have overlapping rather than identical properties for each of the objects. Thus, from the range of possible properties $\mathrm{P}_{1}-\mathrm{P}_{11}$ associated with material individual objects $\mathrm{Coal}_{1}, \mathrm{Coal}_{2}, \mathrm{Coal}_{3}, \ldots$ there will be within each discipline a core of indispensable features, but also a conceivable set of excluded features, that gives rise to that discipline's concept of coal - $\mathrm{C}_{0}, \mathrm{C}_{1}, \mathrm{C} 2$, etc. In other words, each discipline's viewpoint creates the (philosophical) formal object. Among the properties constituting the geologist's coal is the idea of a rock; the power engineer's coal would include source of electricity; the economist's coal might include a commodity caught up in price share movements; and so on (FELBER, 1994, p. 213; ANTIA, 2000, p. 90-92). ${ }^{1}$

At the system level at the top right pane, then, the different disciplinary concepts of coal will be made up of three categories of characteristics corresponding to the previous properties. Each discipline's concept of coal will comprise compulsory, optional and excluded characteristics. Many definitions of concepts in the discipline will draw attention to the compulsory characteristics, sometimes optional conceptual characteristics, but seldom excluded characteristics for pragmatic reasons. In sum, concept $\mathrm{C}_{0}$ has $\mathrm{P}_{1}$ as compulsory characteristic; $\mathrm{P}_{3}, \mathrm{P}_{4}, \mathrm{P}_{5}, \mathrm{P}_{9}, \mathrm{P}_{11}$ are specific to some instances of concept $\mathrm{C}_{0}$; while $\mathrm{P}_{2}, \mathrm{P}_{6}, \mathrm{P}_{7}, \mathrm{P}_{8}$, and $\mathrm{P}_{10}$ are excluded from all instances of Concept $\mathrm{C}_{0}$.

Terminology traditionally distinguishes between a concept and its designation. At the top left pane, which is still at the system level of dictionaries and other normative resources, designations are assigned these concepts in a relatively context-independent manner. At this citational level, $\mathrm{C}_{0}$ is designated $\mathrm{D}_{0}, \mathrm{C}_{1}$ designated $\mathrm{D}_{1}$, etc. In the bottom left pane, where a process of contextualization leads to text-level realizations, we find the rather infelicitous 'contamination' of system-level assignments of term and concept. While there will be situations where the normative relation of term to concept arguably obtains, there will be many other instances of system-text term variation that then give rise to several categories of what Gerzymisch-Arbogast regards as 'contamination'. From the perspective of the term, contamination can manifest when:

a) a term other than the one spe

b) cified at the system level is used interchangeably to represent the same exact concept. This is referred to as contamination of similarity, and is illustrated by example (A) in the lower left pane of Figure 1;

c) a hyperonym (superordinate term) and a hyponym (subordinate term) are used interchangeably so as to represent the other concept. This is referred to as contamination of inclusion, and is illustrated by example (B) in the lower left pane of Figure 1; d) two terms are used interchangeably so as to represent concepts which intersect at the system level. This is referred to as contamination of intersection, and is depicted as example (C) in the lower left pane of Figure 1.

e)

From the perspective of the concept, contamination, according to Gerzymisch-Arbogast (1996), may also manifest in several ways, including:

f) the activation at text level of only a part of the system level concept. This is referred to as partial activation;

g) the use of a term at text level in such a way that the concept which is activated differs from the concept at system level. This is referred to as author-specific usage.

Concept contamination d) and e) above is not shown in Figure 1.

While broadly speaking both integrationism and text-based terminology are keen to interrogate the determinacy of a precontextual sign (which in fact does not exist for integrationism), there are noticeable differences in approach. Integrationism probably rejects as weak segregationism those parts of the terminological account (e.g., accommodation of core features with optional and unforeseeable features that reflect the sign-maker's agency); it rejects any account of the sign that does not pivot on specific communication episodes and activities of the human sign-maker; it probably rejects some of the metalanguage (e.g.,

\footnotetext{
${ }^{1}$ While a conceivable integrationist reaction is to question when a meeting to agree on this convention was held' (a question to which in fact many disciplines may have an answer), Dunker (2019, p. 116), in a recent book clarifying and updating positions in integrationism, offers some validation for this account by referring to repetition. She writes that a "widespread way of reducing indeterminacy in the long run involves repetition directly in making private signs become public. All it takes, in principle, is that a participant identifies a linguistic event as a likely candidate for recontextualization and decides to turn it into a model for repeated selfor other-imitation, each time assigning the "same" semiological value to it, and that other participants treat the model in a similar way"
} 
system vs. text, term vs. concept or signifier vs. signified and similar binaries like type-token to be seen below) and understands a term like contextualization as the birthing of the sign as a result of the integration of the biomechanical, the macrosocial and the circumstantial.

The terminologist may wonder about how or whether, in the integrationist imagination, language in society aligns to Rousseau's account of social formation, that is, of the relationship between individual rights and collective benefits that underpins the social contract. Stated differently, this is a question of whether integrationism's macrosocial parameter can be a communication correlate of the idea that individuals give up aspects of their individual sign-making rights to conform to a collective pattern, so that the sign-maker's interests are better advanced or protected by the might of the collective. Adopting integrationism-speak, terminology may argue that what it considers the system level are collectively shared and sedimented core traces of sign-making episodes, which do not however deprive humans and other parties in communication of their unique agency, their communication aims, and so on. Indeed, terminology may argue that it extends the integrationist's activities (to which humans integrate signs) into the area of assemblages in which signs appear to be agentive, dictating to humans how they integrate subsequent signs (see a discussion on LEMKE, 1999 below).

\section{DECONSTRUCTING A TEXT}

As a means of fostering dialogue between terminology and integrationism, I revisit and extend a previous analysis of a text on parliamentary procedure (ANTIA, 2002). The text is taken from Paul Silk's How Parliament Works, one of several books on the subject by the author. As the title suggests, the book explains parliamentary procedure to a wider public. The interest of the material selected is that it begins with several conceptual/terminological clarifications, which means that one is able to track how consistently these specifications are applied. The excerpts presented are contiguous, with the exception of a later passage containing statistics (and this is indicated below).

In the data sets that excerpts from the book are placed on the left, while to the right are comments I have made to guide reflection and analysis. I am aware that the very metalanguage employed probably skews the suggested analysis and that other analyses are possible. Excerpt 1 below sets the stage.

Excerpt 1

This chapter will look in some detail at these Acts of Parliament ${ }^{1}$ - the basic foundation blocks of the law ${ }^{1}$ - and explore the role which Parliament in practice plays in their making. It will describe the parliamentary procedures which govern delegated legislation, that is legislation ${ }^{1}$ made directly by the government and other bodies who have been authorised by Acts of Parliament ${ }^{1}$ to do so.

First a few basic definitions are needed. When a proposal for a law ${ }^{2}$ is being considered by Parliament, it is known as a bill ${ }^{2}$. When the parliamentary process is complete, if the bill has been agreed to, or ' passed $^{3}$, the bill becomes an Act of Parliament ${ }^{1,2}$ and part of the statute law ${ }^{1}$. It is always referred to by the year in which it was passed ${ }^{3}$. Bills are made up of 'clauses', but when they become Acts ${ }^{2}$ the clauses become known as 'section'.
Analytical comments

${ }^{1}$ In the six instances of this superscript, we infer a sequential relationship between Act and Law/legislation (cf. the basic foundation blocks, have been authorized, and part of)

${ }^{2}$ In the four instances of this superscript, we see that a bill is not a law but a proposal for a law, and that it has a sequential relationship to Act (cf. become/s)

${ }^{3}$ In the two instances of this superscript, 'passed' appears to be introduced as a special collocate of bill (cf. quotation marks) that means agreement.

As the analytical comments show, excerpt 1 sets the stage through a set of explicit and implicit conceptual/terminological clarifications. These clarifications are incidentally quite consistent with the following entries in P.H. Collins' Dictionary of Law $\left(4^{\text {th }}\right.$ edition). London: Bloomsbury Publishing, 2004. 
act noun a statute which has been approved by a law-making body (NOTE: Before an Act becomes law, it is presented to Parliament in the form of a Bill. See notes at bill.)

bill noun 5. a draft of a new law to be discussed by a legislature. The house is discussing the Noise Prevention Bill. The Finance Bill had its second reading yesterday.

pass noun 2. to vote to make a law. Parliament passed the Bill which has now become law.

Legislation noun the set of laws that have been agreed by Parliament and are implemented by the courts.

law noun 1. a written or unwritten rule by which a country is governed and the activities of people and organisations are controlled. A written law in the UK is an Act of Parliament which has received the Royal Assent [...].

I turn now to the analysis of a next set of excerpts, against the backdrop of the clarifications in excerpt 1. In considering excerpt 2 below, the suggested question is: what is the meaning of legislation in this excerpt?

Excerpt 2

Bills and Acts can be divided into two types - public and private. We will consider each separately, but by far the more important are public bills and Acts. These apply throughout the country (though some apply only to Scotland and or only to England and Wales etc.). Private bills and Acts have only a particular local application and are subject to different procedures. For example, a private Act would allow a particular local authority to close a particular cemetery or London Transport to construct a particular new railway line in London's docklands. If new requirements were to be applied to all cemeteries throughout the country or to all new railway lines, these would be contained in public legislation. ${ }^{1}$
Analytical comments

${ }^{1}$ Does legislation in (public) legislation mean:

- a hypernym of both (public) bill and (public) Act?

- (public) Act?

- body of laws

In excerpt 2, the focus is on bills and Acts, their types, and the scope/application of each type. On my reading, altogether, there are seven tokens of bills and Acts, out of which six appear in three iterations of the conjunctive pair bills and Acts - qualified either by private or by public. The one exception, private Act, is used to exemplify a previously defined scope of private bills and Acts. It is in the context of exemplifying the other, the public type, that (public) legislation is used, which then raises the question as to whether the meaning attaching to it is:

- that of the conjunctive pair of (public) bill and Act, or

- (public) Act alone, as in the preceding exemplification of private Act, or

- $\quad$ what a (public) Act that has been successfully processed ultimately becomes (that is, a law).

Correlating legislation with the conjunctive pair of bill and Act is inconsistent with the understanding of legislation in excerpt 1 ; correlating it with Act erases the sequential relationship in excerpt 1.

Consider excerpt 3:

Excerpt 3

${ }^{1}$ Although public legislation applies generally throughout the country, some Acts of Parliament are of far greater importance than others. For example, the 1984-85 session saw proposals for public legislation which ranged from the Local Government Bill, ${ }^{2}$ with its wholesale reform of the metropolitan counties, and the Finance Bill, which implemented the budget proposals, to the Hill Farming Bill, the Race Relations (Welsh Language) Bill and the sale of Alcoholic Beverages from Garage Premises Bill (the last two of these did not become law).
Analytical comments

${ }^{1}$ In the first sentence, is legislation in (public) legislation synonymous to Acts of Parliament?

${ }^{2}$ Has the manner in which the goal of the two bills is stated caused the bills to be understood as Acts/laws? 
Excerpt 3 complicates matters even further. In what I see as the apparent synonymous use of public legislation and Acts of Parliament, there are several things taking place. Firstly, the sequential relationship highlighted in excerpt 1 is not upheld. Secondly, a more generic concept (Acts of Parliament), which is an earlier stage of a process, becomes equated with a later stage that is a more specific outcome (public legislation). Thirdly, bill appears to semantically morph into Act, again somewhat inconsistently with the specification in excerpt 1 . Although the passage informs us that the Local Government Bill and the Finance Bill were two bills that eventually became law, the terminology used (i.e., bill) at the point in time it appears in text is inconsistent with the description. Compare the text's "with its wholesale reform of ..." with a possible alternative: "with its objective of a wholesale reform of...". Compare also the text's "which implemented the budget proposals" with what might have been an alternative consistent with excerpt 1: "which sought to implement the budget proposals". Is meaning sliding from under a definition in the course of text production?

Excerpt 4 is preceded by statistics (deleted) detailing the volume of work done by Parliament.

Excerpt 4

From this it will be obvious that statistics about the number of Acts of Parliament passed $^{1}$ every session are not particularly meaningful. More interesting might be figures for the number of pages of legislation passed ${ }^{1}$ every year. Excluding Consolidation Acts (these are Acts which bring together old legislation in a more convenient way: they do not make new law), in 1980, 1965 pages of public Acts of Parliament were passed ${ }^{1}-$ an average of more than ten pages for every day the commons sat. (Thirty years previously only 430 were passed, ${ }^{1}$ a three day a page average.) A considerable amount of the time of Parliament is occupied in considering the bills which will ultimately become these Acts - in the 1983-86 session almost a third of the Commons' time went in debates on public bills (506 hours out of 1542), and 58 percent of the Lords' time was taken up in this way.
Analytical comments

${ }^{1}$ By virtue of being made to collocate with 'passed' (a special collocate of 'bill' specified in excerpt 1), should the following also be understood in terms of bill: - [number of [Acts of Parliament]] - [number of pages of [legislation]] - [pages of [public Acts of Parliament]] - ten pages Ø, 430 Ø, a page Ø?

On my reading, excerpt 4 provides counterfactuals that invalidate the suggestion or inference in excerpt 1 on pass/ed being a technical verb associated with bill. The inference is not unreasonable considering that the parliamentary term with which passed collocates the most in general usage is bill (see Figure 3). So, passed can reasonably be said to prototypically collate with bill. If passed were correctly specified in extract 1 , we would have to interpret all of its collocates in extract 4 as bill. Thus, bill would be the actual referent for: (public) Acts of Parliament, legislation and the meronymic pages.

\section{A DIALOGUE OF TWO PARADIGMS OVER TEXT}

The above text confirms that terms, not just general language words, can also be "slippery customers", shifting "their meanings and [sliding] out from under any simple definition" (LABOV, 1973, p. 341). The text as I have analyzed it above hopefully provides some evidence for sign indeterminacy. In the apparently shifting meanings of passed, bill, Act and legislation, the integrationist sees evidence for the view that "the sign does not 'have' its own meaning: it is 'made to mean' whatever the circumstances require" (HARRIS; HUTTON, 2007, p. 202).

The phrases "made to mean" and "whatever the circumstances require" highlight for me two points in a discussion of in/determinacies: the role of the sign-maker (their semasiological proficiency, goals, interests) and the agency of circumstances (influencing the sign-maker's signs, sometimes independently of the sign-maker or in a manner that was unplanned for, unforeseeable). The foregoing then makes constant monitoring or reflexivity a feature of communication.

Across excerpts $2-4$ in relation to excerpt 1 and the dictionary entries, indeterminacies, however they are accounted for, pretty much rule, whether it is concern about: 
- $\quad$ how I as a reader am made to grapple with possible understandings of public legislation - as a conjunctive pair of public bill and Act, or as public Act alone, or as what a public Act that has been successfully processed ultimately becomes;

- the inconsistency in the logical/sequential relations declared between bill and Act, Act and law; or what is happening when a more generic concept (Acts of Parliament), which is an earlier stage of a process, becomes equated with a later stage that is a more specific outcome (public legislation);

- $\quad$ how I am to decipher if every noun made to collocate with pass/ed is a bill.

Clearly, I am monitoring the signs placed on the page by author Paul Silk. Silk is making his signs and my reflexivity shows that I am not passively assimilating Silk's signs. I am using my creative interpretative faculties. In other words, telementation is not at work here, at least not for me as a trained text analyst. But how far should reflexivity be pushed here? Not every sign in the text was indeterminate. It is a moot point whether a reader with a different semasiological proficiency would have processed the selected signs as dynamically as I have done to identify indeterminacies, or the reader would have proceeded synoptically and have been less alert to indeterminacies. ${ }^{2}$

In introducing the second point, that is, the circumstances into which signs are integrated, let me refer to Lemke's work on how co-texts may affect the constitution of a sign:

We all have had this experience in writing. We begin to write about something, and in the course of writing, we happen to choose a particular word when we might just as well have used another; then a particular grammatical construction that also was only one possible way-of-saying, and the result is that two unplanned words are brought into an unexpected juxtaposition and ... lead to a formation not part of our original plan. (LEMKE, 1991, p. 34)

Elsewhere, Lemke (1991, p.33) writes:

\begin{abstract}
What we first wrote or said was one way of instantiating a part of the original text plan, and only some its features were specified by that plan. Now we must go on to instantiate another part of the text plan, and again it will specify only some features. But how we instantiate those features now depends not just on the text-plan requirements, but also on how we happened to instantiate those of the previous portion(s) of the text. Principles of consistency now come into play that make previously irrelevant, 'incidental' features highly relevant for text production.
\end{abstract}

Lemke would seem to be hinting at assemblages, that is, the temporary arrangement of things, the bringing together of things to function in new ways. For Pennycook (2017) assemblages enable us to reflect on how agency, cognition, and language may be distributed in ways that de-center the human. Given its rejection of the "distance principle" (DUNKER, 2017, p. 164), integrationism probably denies that words/assemblages have any force independent of their human users, ostensibly because the assemblages reflect the communicational experiences and proficiencies of particular individuals. Building on Lemke, terminology would claim that a range of communicational considerations (e.g., perspectivization, textual factors) do produce indeterminacies. Sometimes these factors are unplanned and independent of the text author; at other times they may be planned but with consequences the author may not have anticipated. Let me illustrate.

Excerpt 1 comes across as a pedagogical context; it teaches in such a way that the signs it uses (bill, act, law) are in an ideal, uncontaminated relationship with system level specifications. Adopting integrationism-speak in part, terminology might suggest that the manner in which Paul Silk has constituted a set of signs (bill, Act, law), that is, integrated them into the pedagogical-type

\footnotetext{
${ }^{2}$ Lemke (1991) distinguishes dynamic and synoptic processing of signs in text. In dynamic text processing, "one enters into the flow of events and asks what is the meaning of an utterance as it occurs and what meaning attaches to how and when it is occurring. [...] Meanings are taken to be more tentative ... their timeliness and manner more signifying" (LEMKE, 1991, p. 26). This is evidently how much of the analysis of the legislative text has taken place and has unearthed examples of momentary indeterminacies. In the synoptic perspective, we "step outside the flow of events and examine meanings retrospectively, in the full context of a social event as it has occurred ... focusing the what-could-be-meant of dynamic meaning into the what-evidently-must-have-been-meant of synoptic meaning" (LEMKE, 1991, p. 26).
} 
situation in excerpt 1 , does not differ from a core of sedimented conventionalized traces, at system level (e.g., Collins' dictionary), of previous constitutions of replicas of these signs.

In excerpt 2, we see how a concern for pedagogy (e.g., 'Bills and Acts can be divided into two types') raises a text production constraint: the inefficiency of maintaining the conjunctive pair of bills and Acts beyond three iterations. In exemplifying the preceding functional description of private bills and Acts, bill is dropped in favor of Act. Thus, we move from:

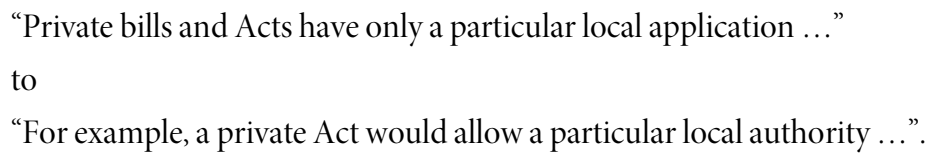

However, in the following sentence exemplifying the public type of the conjunctive pair, legislation is used. This creates a situation where the reader, on encountering

"If new requirements were to be applied to all cemeteries throughout the country or to all new railway lines, these would be contained in public legislation"

has to wonder if legislation as the head of the compound is to be processed in the pedagogical sense of body of laws or in the shifting, rough-and-tumble sense of any of Act or hypernym of bill and Act.

In excerpt 3, the putative awkwardness of repeating public legislation in the same sentence sees the author introduce different terminology, Act of Parliament. But as was seen earlier, the response to this particular textual constraint produced the effect that a specific type of outcome (public legislation) was used with what is in fact a stage (Acts of Parliament) and a generic one at that, to designate a single referent. Rather than a case of hyponymy and hypernymy, what we see here are two terms whose meanings intersect.

The specific focus of excerpt 4 is on quantifying Parliament's productivity, and the collocate passed is applied to quantifications of each of Acts of Parliament, legislation, and public Acts of Parliament, but not to bill which one would have expected from excerpt 1. The focus on quantification in excerpt 4 sees pages occurring with legislation and Acts of Parliament in several of the noun phrases. As the excerpt unfolds, however, a need for economy arises. As a result, the noun phrases progressively shed Acts of Parliament/legislation, leaving figures and pages to collocate with passed.

To return to integrationism-speak, the foregoing discussion has shown how a set of terms have been made to mean what different circumstances required them to mean (or how different circumstances funneled meanings into certain terms). It is evident how terminology can recast its rejection of the exceptionalism of sign stability in special purpose texts as a rebuttal of telementation, or why some reflexivity ought to be integral to processing special purpose texts. On the other hand, integrationism may see that discourse structures and word collocations, not just non-verbal activities, constitute a part of the framework into which specific signs may be integrated in order to become meaningful.

\section{CRITIQUING INTEGRATIONISM: PERSPECTIVES FROM TEXT-BASED TERMINOLOGY}

Radical indeterminacy in integrationism, the idea that a linguistic sign does not pre-exist its context and is constantly being made and remade, is a problematic proposition in spite of how the evidence of the above text analysis may be enlisted to support it. Corpus frequencies would seem to provide a strong rationale for integrationism to pull back from the brink of radical indeterminacy. While integrationism's focus on peculiar particulars would suggest an outright rejection of corpus analysis, a recent attempt at re-theorizing the macrosocial pillar in terms of a system, specifically, how to bridge the hiatus between the individual and the population levels (DUNKER, 2017) interestingly provides legitimacy for the corpus. Dunker (2017: 136) quotes Harris as acknowledging that "[m]acrosocial features of communication show up clearly only when communicative behavior is 
studied en masse (HARRIS, 1984, p. 280)". A corpus of legislative discourse is a resource for studying the communicative behavior of parliamentary students and practitioners.

In spite of confirmation for integrationist principles in the parliamentary text analyzed, an examination of the collocates of legislation in Hansard Corpus of the British Parliament (2020) reveals that usage in the text is after all not as idiosyncratic as one was led to believe. In the rough-and-tumble of real-world communication, legislation has indeed been used as a hypernymous synonym of Act and bill. Consider Figure 2.

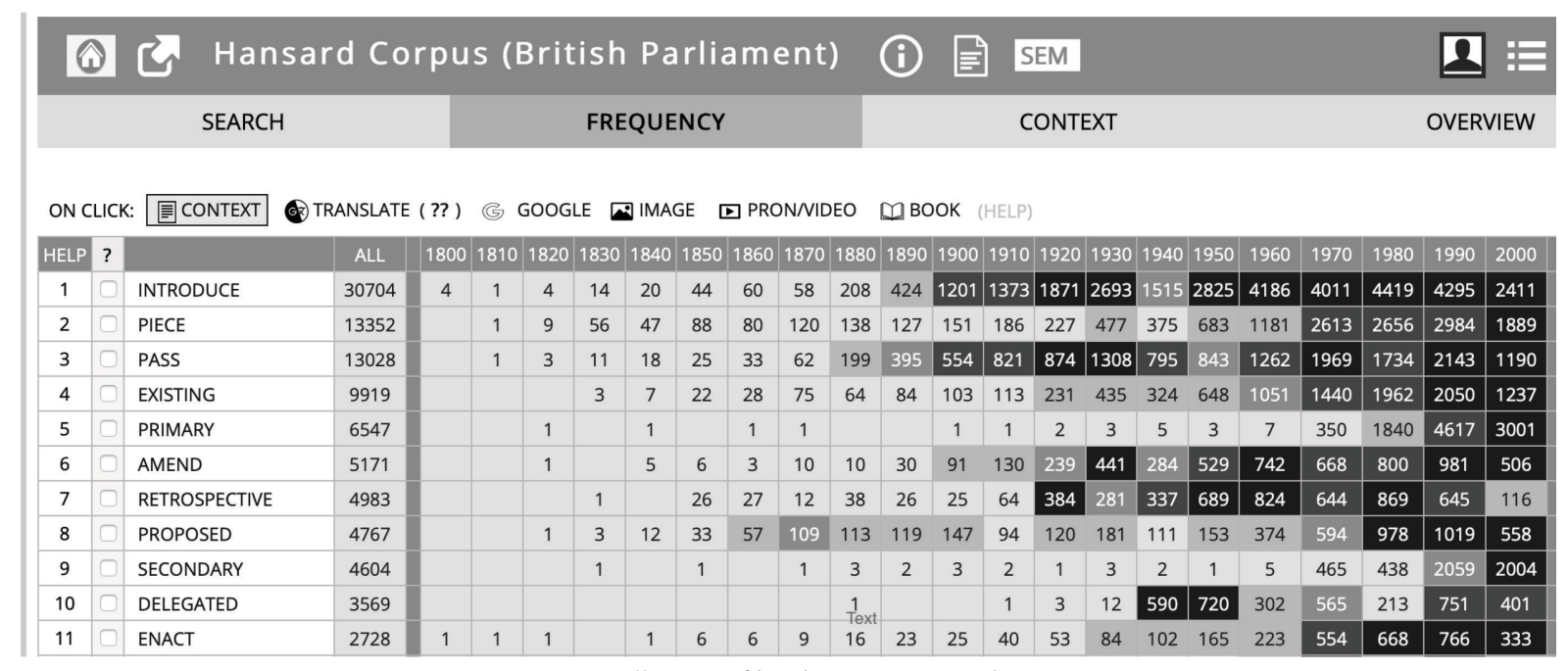

Figure 2: Collocates of legislation in Hansard Corpus

Source: Hansard Corpus (2020)

As Figure 2 shows, from text corpora dating back to the 1800s, legislation (in the British Parliament) has been introduced and passed (sensu bill?), amended and enacted (sensu Act?), and made to collocate with existing (sensu law/body of laws?). The foregoing is in part confirmed by Figure 3 which displays introduce as a collocate of legislation.

\begin{tabular}{|l|}
\hline the Government to prevent hon: Members from exercising their right to introduce private Members' legislation in the House? § \\
of tonight's debate: The Government had an opportunity to introduce the television licences legislation earlier, if indeed they needed to introduce it at all, but they are \\
: formula for widows' entitlement to SERPS, which was introduced in the 1986 legislation? Indeed, will he confirm that they carry that formula through into the state \\
\hline 1979 and 1997: The hon: Gentleman represents the party that introduced the British nationality legislation, that brought in the primary purpose rule and that in 1993 ak \\
the Member for Mid-Sussex could have guaranteed it when it was introduced in the 1996 legislation: That is fair enough, but we have been told time and again in \\
\hline sure that they have been very useful: They have also introduced a raft of legislation that directly impacts on young people, but they have never seriously set out to \\
\hline only the Government could--; or, arguably, should--; introduce that type of legislation: We all recognise that such legislation would be controversial: Liberty still condemn \\
hon: Friend has assured the House that the regulations will be introduced and the primary legislation changed at the earliest possible opportunity: May I urge him to use \\
\hline imposing new ones: There is no point in the Government introducing further criminal justice legislation if the police officers are not in place to enforce existing legislatio \\
\hline in due course, they will be given the opportunity to introduce even more progressive legislation, particularly in that sector: \\
of comprehensive and swiftly considered legislation: I plead guilty to introducing prices and incomes legislation; the first Bill on consumer credit; one of the early Bills or
\end{tabular}

Figure 3: Introduce as collocate of legislation in Hansard Corpus

Source: Hansard Corpus (2020)

The first and last concordance lines of Figure 2 clearly show how legislation is used synonymously with bill in the British Parliament. These apparent synonyms occur across a variety of texts (hence contexts) in this corpus.

The problem that arises, then, is as follows. Some of what was analyzed as indeterminacies are not in fact aberrations, but they reflect a historical pattern which might suggest some social convention. Paradoxically, an attested pattern of indeterminacies still does not rule out the prospect of singular, further indeterminacies. The point as to where some of these patterns or conventions are located is as moot as a question on the location of certain forms of conduct that guide community life. Now, integrationism, as seen earlier, considers it erroneous "to start with the notion of a social convention already in situ. For our own experience tells us that we attribute significations to things and events, irrespective of whether there is any social convention about the matter or not. 
Signs do not necessarily have a social dimension at all" (HARRIS, 1996, p. 67-8). This is a complex rhetorical move that has been traditionally interpreted as meaning that social convention plays no role at all in the constitution of the integrationist sign. Harris appears to be making two comments here. The first is that there may be social convention in the identification of a sign, but this is neither a necessary nor a sufficient condition. If "necessarily" is not a hedge that weakens the argument to strengthen the claim, Harris' second point is that social convention plays no role at all in the constitution of the sign.

To resolve the conundrum associated with apparent, corpus-derived counterfactuals to the traditional outright rejection of social convention in integrationism, a rhetorical move that builds on Harris' first point commends itself. This is especially so in light of Harris' view that

Where the integrationist parts company with the segregationist is not in declining to recognize [the] continuous chain of communication stretching endlessly back into the past, but in declining to accept it as a sufficient warrant for assigning to communicational codes or conventions a theoretical status which makes them both logically and pragmatically prior to their use. (HARRIS, 1996, p. 32)

The above view, in many respects liberatory and profound, reframes the problématique of the sign: does past use of a sign automatically confer sign status on a formal replica encountered later? Answering in the negative, without qualifying the answer, would raise questions of efficiency in communication. Wouldn't the intellectual resources of my addressees be expended entirely on metacommunicating, rather than on communicating? Is limited efficiency in communicating the price to pay for rejecting telementation? Fortunately, there is as previously hinted (footnote 1) a process of securing mutual understanding that appears to dispense with constant monitoring, and that process requires no more than "[...] that individuals project on to others the kind of understanding they have developed of the linguistic interactions they themselves engage in" (LOVE, 1990, p. 109 apud DUNKER, 2017, p. 116).

Discourse proceeds by repetition and variation, as Johnstone remind us. In her words, a "[...] person whose discourse was completely creative - completely unlike anything previously tried - would, after all, be impossible to understand" (JOHNSTONE, 2008, p. 163). Discussing how creativity and cliché are accommodated in the design of language, Hanks similarly reminds that

$[\ldots]$ the creative potential of language is undeniable, but the concordances to a corpus remind us forcibly that in most of our utterances we are creatures of habit, immensely predictable, rehearsing the same old platitudes and the same old clichés in almost everything we say. If it were not so, ordinary language would become unworkable. Humankind cannot bear very much creativity. (HANKS, 2013, p. 141)

A sign model that accommodates determinacy and indeterminacy is clearly required. A model along the lines of GerzymischArbogast's that accommodates compulsory and optional (perhaps unforeseen features) finds some support in Beaugrande's (1997) account of the adaptive and other characteristics of complex systems. For Beaugrande, a text, theory, cognition, communication, and so on, are all instances of complex systems. In his account, a complex system is a combination of in-built and emergent features; in other words, interaction between standing constraints and emergent constraints takes place constantly in such a system. By design or by their very nature, complex systems need to be seen as existing as continua along the following dimensions:

- stability $\leftarrow \rightarrow$ fluctuation: the extent to which the system can retain or alter its current state (shape, form),

$\circ \quad$ familiarity $\leftarrow \rightarrow$ novelty: the extent to which the system confirms or disconfirms a known or an expected state,

$\circ \quad$ simplicity $\leftarrow \rightarrow$ complexity: the extent to which entities in a system and their mutual interactions are few and uniform versus numerous and varied,

- determinacy $\leftarrow \rightarrow$ indeterminacy: the extent to which "decisions among competing alternatives are clear or unclear" (BEAUGRANDE, 1997, p. 88).

An appreciation of the design parameters of a complex system spawns a mindset which does not view "[...] stability, determinacy, and so on, as fixed static qualities" but as "dynamic factors undergoing drifts and transactions" (BEAUGRANDE, 1997, p. 88). With such a mindset, “[...] we can then inquire how the 'features', 'properties, 'structures' and so on, we encounter may have 
emerged and evolved" (BEAUGRANDE, 1997, p. 88). Ultimately, sense is made of these drifts and transactions through a mechanism of control, a further feature of complex systems. To "[...] control a domain, you apply the standing constraints specified in your model of it with the emergent constraints it is manifesting and thereby attain a convergent framework for cognitive, discoursal and social moves" (BEAUGRANDE, 1997, p. 89).

Applying this model to the legislative text analyzed, we readily make connections to questions that arose around the extent to which meanings (agree to, proposal for a law, agreed to proposal, body of laws) can retain versus alter the form used to refer to them; or the extent to which forms confirm or disconfirm expected meanings; etc. The model legitimizes an inquiry into how the terminological/conceptual specification in excerpt 1 evolved across subsequent excerpts. The hermeneutic process associated with our dynamic reading exemplifies the notion of control, which involves, as was the case in the dynamic reading, level-shifting or reassignment of the text's resources (finding meaning not in a given sign under analysis, but in other signs, discourse structures, etc.).

The model steers a middle course between the total determinacy of structuralism and the radical indeterminacy of poststructuralism. It is easily seen as contextualizing, within this middle space, a number of integrationist concepts, even with some commitment to the role of social convention in the constitution of the sign. To view the sign/term through the lens of Beaugrande's complex system is: (1) to reject the myth that language is all completely pre-engineered ahead of specific contexts of use; (2) to acknowledge that, in meaning whatever the circumstances require it to mean (because of emergent constraints), the sign need not be cut off the apron strings of social convention (ANTIA; MAFOFO, 2021); (3) relatedly, to acknowledge that some reflexivity or monitoring is an integral feature of language use; (4) thus, to rule out transmission or telementation as a principle that adequately describes meaning-making; and (5) to draw on the preceding points to make critical learning possible.

\section{CONCLUSION}

In their respective scholarship, integrationism and text-based terminology continue a tradition of jolting us out from an uncritical mentalism about signs, for instance, word meanings. They both draw attention to the weaknesses of not engaging with the sign in the particular contexts of its occurrence. They do so in different ways. Integrationism understands the sign in a way that denies it a pre-context existence; it argues that there are factors in the circumstances of the use of a sign that make every such (contextually) constituted sign unique; it thus underscores the singularity of a sign's occurrence; it holds that traces left by a unique sign do not obviate the need for a fresh sign reconstitution on another occasion; the ineluctable creativity or novelty associated with every sign, and the attendant indeterminacies, makes monitoring integral to the processes of communicating; the latter underscores why communication is not telementation. Text-based terminology recognizes that terms and the concepts they designate are constituted in ways that accommodate a core of features that are conventionally regarded, for a time, as essential, and features that are optional (and perhaps unforeseeable). Dictionaries (including electronic ones) and databases are representations of timebound conventionalized or patterned accounts of these terms-concepts, with the affordances of technology being leveraged to identify core and aberrant acceptations in an unprecedented manner. Terminology's decompositional approach to the sign, reminiscent of the structural semantics tradition, allows it in part to explain indeterminacies in terms of contextual perspectivization, a range of textual considerations, and so on.

Terminologists would find aspects of the integrationist conception of language and of the sign in particular as enriching their own metalanguage and conceptualization; they would easily see the special purpose text analyzed in this article as confirming several tenets of integrationism. Terminologists, however, would find it difficult to totally deny social (in their case, disciplinary) convention in their approach to the term as a sign; they are more at ease with a view of the sign as a dynamic interaction between standing constraints (admittedly capable of shifting) and emergent constraints. They find corpus evidence for signs that conform to models that highlight core or standing constraints alone, but that also conform to models of both constraint types. Terminologists are not sold on integrationist criticisms of corpus linguistics, and they might wonder about the implications of integrationism's radical indeterminacy in a range of text comprehension tasks. 
Perhaps, ultimately, the difference between both paradigms is one of degree, rather than of kind - degree or granularity of description of what a sign is. Given their respective takes on the role of antecedence and the nature of (situational) relevance, integrationism has a much higher threshold for defining what a sign is in comparison to terminology.

\section{REFERENCES}

AHMAD, K. A terminology Dynamic and the Growth of knowledge: A Case Study in Nuclear Physics and in the Philosophy of Science. In: GALINSKI, C.; SCHMITZ, K-D. (ed.). TKE'96: Terminology and Knowledge Engineering. Frankfurt/M: Indeks, 1996. p. 1-11.

ANTIA, B.E.; MAFOFO, L. Text Annotations: Examining Evidence for a Multisemiotic Instinct and the Intertextuality of the Sign in a Database of Pristine Self-directed Communication. In: MAKONI, S.; KAIPER-MAQUEZ, A.; VERITY, D. (ed.). Integrational Linguistics and Philosophy of Language in the Global South. London: Routledge Press, 2021. p. 84 - 103.

ANTIA, B.E.; KAMAI, R. A. Writing Biology, Assessing biology: The Nature and Effects of Variation in Terminology. Terminology: International Journal of Theoretical and Applied Issues in Specialized Communication, v. 22, n. 2, p. 201-223, 2016.

ANTIA, B.E. (ed.). Indeterminacy in LSP and Terminology: Studies in Honour of Heribert Picht. Amsterdam/Philadelphia: John Benjamins, 2007.

ANTIA, B.E. II termine: contesto definitorio e contesto d'uso In: MAGRIS, M.; MUSACCHIO, M.T.; REGA, L.; SCARPA, F. (ed.). Manuale di terminologia. Aspetti teorici, metodologici e applicativi. Milan: Hoepli, 2002. p. 99-114.

ANTIA, B.E. Terminology and Language Planning: An Alternative Framework of Discourse and Practice. Amsterdam/Philadelphia: John Benjamins, 2000.

BADE, D.; PABLÉ, A. Signs Unfounded and Confounded. A reply to Søren Lund. RASK. International Journal of Language and Communication, v. 35, n. 1, p. 43-85, 2012.

BEAUGRANDE, R. New Foundations for a Science of Text and Discourse: Cognition, Communication, and the Freedom of Access to Knowledge and Society [vol. LXI of Advances in Discourse Processes]. Norwood: Ablex, 1997.

BOWKER, L. A Descriptive Study of the Influence of Multidimensionality on Term Formation and Use with Special Reference to the Subject Field of Optical Scanning Technology. Terminology: International Journal of Theoretical and Applied Issues in Specialized Communication, v. 4, n. 2, p. 275-302, 1987.

CABRÉ, M.T. Terminology. Theory, Methods and Applications. Amsterdam/Philadelphia: John Benjamins, 1998.

CHIRONDO, K. Rhetoric and Integrationism. In: MAKONI, S.; KAIPER-MAQUEZ, A.; VERITY, D. (ed.). Integrational Linguistics and Philosophy of Language in the Global South. London: Routledge Press, 2021. p. 122-136.

CONDAMINES, A. Variations in Terminology: Application to the Management of Risks Related to Language Use in the Workplace. Terminology: International Journal of Theoretical and Applied Issues in Specialized Communication, v. 16, n. 1, p. 30-50, 2010 .

DUNKER, D. The Reflexivity of Language and Linguistic Inquiry. Integrational Linguistics in Practice. Oxon: Routledge, 2019. 
DUNKER, D. The Notion of an Integrated System. In: PABLÉ, A. (ed.). Critical Humanist Perspectives. The Integrational Turn in Philosophy of Language and Communication. London: Routledge, 2017. p. 135-153.

FELBER, H. The Correspondence of Object, Concept \& Symbol. In: DRASKAU, J. K.; PICHT, H. (ed.). Terminology Science \& Terminology Planning/Theoretical Issues of Terminology Science [IITF Series 4]. Vienna: TermNet, 1994. p. $209-216$.

FLUCK, H-R. Fachsprache. Tübingen: Francke, 1991.

GERZYMISCH-ARBOGAST, H. Termini im Kontext. Verfahren zur Erschließung und Übersetzung der textspezifischen Bedeutung von fachlichen Ausdrücken. Tübingen: Gunter Narr (FFF, vol. 31), 1996.

HALLIDAY, M. A. K. AND MARTIN, J. R. Writing Science. Literacy and Discursive Power. London: The Falmer Press, 1993.

HANKS, P. Lexical Analysis: Norms and Exploitations. Cambridge, Massachusetts: The MIT Press, 2013.

HANSARD CORPUS. British Parliament. 2020. Available in: https://www.english-corpora.org/hansard/. Acess in. Dec. 2020.

HARRIS, R. Signs, Language, and Communication: Integrational and Segregational Approaches. London \& New York: Routledge, 1996.

HARRIS, R. Integrationism. A very brief introduction, 2015 Available in: https://www.royharrisonline.com/integrational_linguistics/integrationism_introduction.html> Accessed: 15 June 2021.

JOHNSTONE, B. Discourse Analysis. Malden, MA: Blackwell Publishing, 2008.

LABOV, W. The Boundaries of Words and their Meanings. In: BAILEY C-J.; SHUY, R. (ed.). New Ways of Analyzing English. Georgetown University School of Languages and Linguistics, 1973, p. 340-373.

LEMKE, J.L. Talking Science: Language, Learning, and Values. Norwood, N.J: Ablex Publishing Company, 1990.

MAKONI, S.; KAIPER-MAQUEZ, A.; VERITY, D. (ed.). Integrational Linguistics and Philosophy of Language in the Global South. London: Routledge Press, 2020.

MAKONI, S. The Lord Is My Shock Absorber: A sociohistorical integrationist approach to mid-twentieth-century literacy practices in Ghana. In: BLACKLEDGE, A.; CREESE, A. (ed.). Heteroglossia as practice and pedagogy. Dordrecht: Springer, 2014. p. 75-97.

NEWMARK, P. Looking at English Words in Translation. In: Anderman, G.; Rogers, M.A. (ed.). Words, Words, Words. Clevedon: Multilingual Matters, 1996. p. 56-62.

PECMAN, M. Variation as Cognitive Device: How Scientists Construct Knowledge through Term Formation. Terminology, v. 20, n. 1, p. 1-24, 2014.

PICHT, H.; DRASKAU, J. K. Terminology: An Introduction. Surrey: University of Surrey, 1985. 
ROGERS, M.A. Translating Terms in Text: Holding on to Some Slippery Customers. In: ANDERMAN, G.; ROGERS, M.A. (ed.). Word, Text, Translation. Liber Amicorium for Peter Newmark. Clevedon: Multilingual Matters, 1999. p. 104-116.

ROGERS, M. Lexical Chains in Technical Translation: A Case Study in Indeterminacy. In: ANTIA, B.E. (ed.). Indeterminacy in LSP and Terminology: Studies in Honour of Heribert Picht. Amsterdam/Philadelphia: John Benjamins, 2007. p. 15-35.

ROGERS, M. Consistency in Terminological Choice: Holy Grail or False Prophet? Synaps. Fagspråk, Kommunikasjon, Kulturkunnskap. (Festskrift for Magnar Brekke), v. 21, p. 107-113, 2008.

SABINO, R. Beyond IL: Languaging without Languages. In: MAKONI, S.; KAIPER-MAQUEZ, A.; VERITY D. (ed.). Integrational Linguistics and Philosophy of Language in the Global South. London: Routledge Press, 2021. p. 183-196.

SAGER, J. C. A Practical Course in Terminology Processing. Amsterdam/Philadelphia: John Benjamins, 1990.

SILK, P. How Parliament Works. London: Longman, 1987.

QUINE, W. V. O. Word and Object. Cambridge: The Massachusetts Institute of Technology Press, 1960.

WRIGHT, S. E.; BUDIN, G. (ed.). Handbook of Terminology Management [vol. 1]. Amsterdam/Philadelphia: John Benjamins, 1997.

WITTGENSTEIN, L. Philosophical investigations. Transl. G.E.M. Anscombe. Oxford: Basil Blackwell, 1953.

\section{(다)(1) (3) $\ominus$}

Received on September 23, 2021. Approved on December 17, 2021. 